\title{
Functional properties of bacterial communities in water and sediment of the eutrophic river-lake system of Poyang Lake, China
}

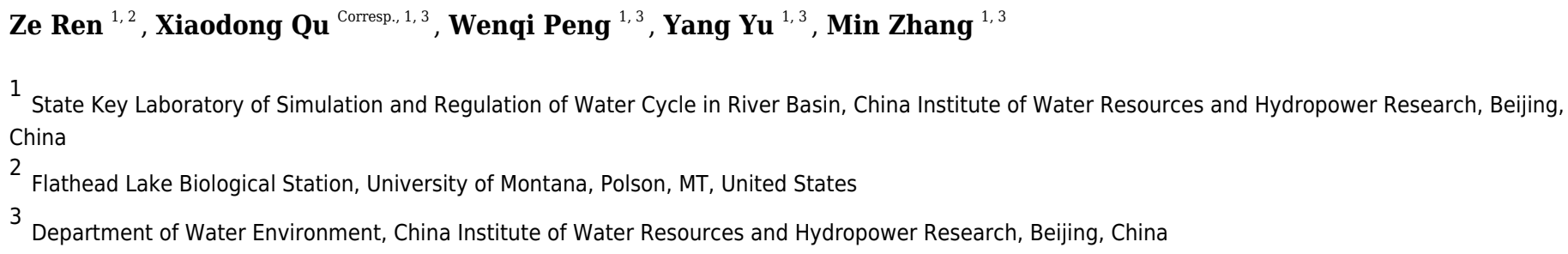

In river-lake systems, sediment and water column are two distinct habitats harboring different bacterial communities which play a crucial role in biogeochemical processes. In this study, we employed PICRUSt (Phylogenetic Investigation of Communities by Reconstruction of Unobserved States) to assess the potential functions and functional redundancy of the bacterial communities in sediment and water in a eutrophic river-lake ecosystem, Poyang Lake in China. Bacterial communities in sediment and water had distinct potential functions of carbon, nitrogen, and sulfur metabolisms as well as phosphorus cycle, while the differences between rivers and the lake were inconspicuous. Bacterial communities in sediment had a higher relative abundance of genes associated with carbohydrate metabolism, carbon fixation pathways in prokaryotes, methane metabolism, anammox, nitrogen fixation, and dissimilatory sulfate reduction than that of water column. Bacterial communities in water column were higher in lipid metabolism, assimilatory nitrate reduction, dissimilatory nitrate reduction, phosphonate degradation, and assimilatory sulfate reduction than that of sediment bacterial communities. Furthermore, the variations in functional composition were closely associated to the variations in taxonomic composition in both habitats. In general, the bacterial communities in water column had a lower functional redundancy than in sediment. Moreover, comparing to the overall functions, bacterial communities had a lower functional redundancy of nitrogen metabolism and phosphorus cycle in water column and lower functional redundancy of nitrogen metabolism in sediment. Distance-based redundancy analysis and mantel test revealed close correlations between nutrient factors and functional compositions. The results suggested that bacterial communities in this eutrophic river-lake system of Poyang Lake were vulnerable to nutrient perturbations, especially the 
bacterial communities in water column. The results enriched our understanding of the bacterial communities and major biogeochemical processes in the eutrophic river-lake ecosystems. 
1 Functional properties of bacterial communities in water and sediment of the eutrophic river-

2 lake system of Poyang Lake, China

3 Ze Ren ${ }^{1,2}$, Xiaodong $\mathrm{Qu}^{1,3^{*}}$, Wenqi Peng ${ }^{1,3}$, Yang Yu ${ }^{1,3}$, Min Zhang ${ }^{1,3}$

$4{ }^{1}$ State Key Laboratory of Simulation and Regulation of Water Cycle in River Basin, China

5 Institute of Water Resources and Hydropower Research, Beijing 100038, China

$6 \quad{ }^{2}$ Flathead Lake Biological Station, University of Montana, Polson, MT 59860, USA

$7{ }^{3}$ Department of Water Environment, China Institute of Water Resources and Hydropower

8 Research, Beijing 100038, China

9 *Corresponding Author:

10 Xiaodong Qu

11 Department of Water Environment, China Institute of Water Resources and Hydropower Research,

12 Beijing 100038, China.

13 Email: quxiaodong@iwhr.com 


\section{Abstract}

15 In river-lake systems, sediment and water column are two distinct habitats harboring different

16 bacterial communities which play a crucial role in biogeochemical processes. In this study, we

17 employed PICRUSt (Phylogenetic Investigation of Communities by Reconstruction of

18 Unobserved States) to assess the potential functions and functional redundancy of the bacterial

19 communities in sediment and water in a eutrophic river-lake ecosystem, Poyang Lake in China.

20 Bacterial communities in sediment and water had distinct potential functions of carbon, nitrogen,

21 and sulfur metabolisms as well as phosphorus cycle, while the differences between rivers and the

22 lake were inconspicuous. Bacterial communities in sediment had a higher relative abundance of

23 genes associated with carbohydrate metabolism, carbon fixation pathways in prokaryotes, methane

24 metabolism, anammox, nitrogen fixation, and dissimilatory sulfate reduction than that of water

25 column. Bacterial communities in water column were higher in lipid metabolism, assimilatory

26 nitrate reduction, dissimilatory nitrate reduction, phosphonate degradation, and assimilatory

27 sulfate reduction than that of sediment bacterial communities. Furthermore, the variations in

28 functional composition were closely associated to the variations in taxonomic composition in both

29 habitats. In general, the bacterial communities in water column had a lower functional redundancy

30 than in sediment. Moreover, comparing to the overall functions, bacterial communities had a lower

31 functional redundancy of nitrogen metabolism and phosphorus cycle in water column and lower

32 functional redundancy of nitrogen metabolism in sediment. Distance-based redundancy analysis

33 and mantel test revealed close correlations between nutrient factors and functional compositions.

34 The results suggested that bacterial communities in this eutrophic river-lake system of Poyang

35 Lake were vulnerable to nutrient perturbations, especially the bacterial communities in water 
36 column. The results enriched our understanding of the bacterial communities and major

37 biogeochemical processes in the eutrophic river-lake ecosystems.

38 Keywords carbon metabolism, nitrogen cycle, biogeochemistry, bacterial community, tributaries,

39 eutrophication 


\section{Introduction}

41 Lakes and their tributaries are highly linked ecosystems in multiple ways, especially through

42 materials transported from the watershed to the lake through river systems (Cole et al, 2006;

43 Marcarelli and Wurtsbaugh, 2009; Jones, 2010; Ylla et al, 2013). Microbial communities in lake

44 and its tributaries have different taxonomic compositions (Ren et al, 2017a, 2019). In lake

45 ecosystems, water and sediment are two distinct realms and interact closely through

46 biogeochemical processes (Parker et al, 2016). These two habitats host tremendous diversity of

47 microorganisms (Lozupone and Knight, 2007; Roeske et al, 2012; Huang et al, 2016), which

48 constitute distinct microbial communities in sediment and water column (Briee et al, 2007;

49 Nishihama et al, 2008; Ren et al, 2019). However, the functional differences of bacterial

50 communities in sediment and water column of lake-river systems were not well studied.

51 In aquatic ecosystems, bacterial communities play an extremely important role in transformation,

52 accumulation, and migration of nutrients and other elements, as well as in energy conversion and

53 material recycling (Cotner and Biddanda, 2002; van der Heijden et al, 2008; Newton et al, 2011).

54 Bacterial communities exhibit high compositional and functional variability (Newton et al, 2011).

55 Functional traits are valuable ecological markers to understand the bacterial community assembly

56 (Barberan et al, 2012). Moreover, microbial metabolic activities can influence water quality

57 through the storage and release of nutrients (Nielsen et al, 2006; Hupfer and Lewandowski, 2008).

58 Thus, it is crucial to understand the roles of bacterial communities in biogeochemical cycling and

59 elucidate their responses to environmental changes by unraveling their functional potentials (Green

60 et al, 2008; Fierer et al, 2012; Freedman and Zak, 2015; Ren et al, 2017b). In addition, previous

61 studies suggested that distinct taxa can share specific functional attributes while closely related

62 taxa may exhibit distinct functional features (Allison and Martiny, 2008; Philippot et al, 2010; 
63 Fierer et al, 2012; Dopheide et al, 2015). Thus, the relationships between taxonomic and functional

64 differences can help to elucidate functional redundancy and stability of bacterial communities.

65 Changes in water quality and sediment properties drive the variation of bacterial communities

66 which regulate the core biogeochemical processes such as carbon and nitrogen metabolisms in

67 aquatic ecosystems (Liu et al, 2018; Wang et al, 2018; Yao et al, 2018). As the largest freshwater

68 lake in China, Poyang Lake is fed by five tributaries and is experiencing aggravated nutrient

69 loading from agriculture and urbanization of the catchment in recent decades (Wang and Liang,

70 2015; Liu et al, 2016a). The increase in nutrient inputs caused by agriculture, urbanization, and

71 industry has significantly degraded water quality and ecological integrity of Poyang Lake with

72 serious eutrophication (Wang et al, 2015; Zhang et al, 2015; Liu et al, 2016a). In the river-lake

73 systems of Poyang Lake, our previous study has shown that the taxonomic composition of bacterial

74 communities in lake sediment, river sediment, lake water, and river water had distinct spatial

75 distribution patterns and close relationships with nutrients (Ren et al, 2019). However, our

76 understanding of the functions mediated by the bacterial communities in the sediment and water

77 of this linked river-lake ecosystem is still limited. To reveal the functional potentials of bacteria,

78 metagenomic sequencing has been used in a growing number of studies (Mackelprang et al, 2011;

79 Fierer et al, 2012; Llorens-Marès et al, 2015). Alternatively, PICRUSt (Phylogenetic Investigation

80 of Communities by Reconstruction of Unobserved States) is cheaper, faster, and reliable

81 (Wilkinson et al, 2018) and has been widely used to infer the functional profile of the bacterial

82 communities using 16S rRNA genes and a reference genome database to predict the functional

83 composition of a metagenome (Langille et al, 2013). In this study, we predicted metagenomes

84 from 16S rRNA gene sequences and classified into KOs (Kyoto Encyclopedia of Genes and

85 Genomes Orthologs) using PICRUSt. The KOs associated with carbon, nitrogen, and sulfur 
86 metabolisms as well as phosphorus cycle were identified from KEGG database (Kanehisa and

87 Goto, 2000). We aimed to reveal the functional properties of bacterial communities in lake

88 sediment (SL), river sediment (SR), lake water (WL), and river water (WR) in the river-lake system

89 of Poyang Lake, including (1) metabolism pathways of major functions, (2) influences of nutrient

90 variables on functional compositions, and (3) functional redundancy.

\section{Materials \& Methods}

\section{Study area and field sampling}

93 Poyang Lake is located in the lower reach of Yangtze River. With a surface area over $4000 \mathrm{~km}^{2}$

94 (in summer), it is the largest freshwater lake in China. There are five rivers (Fuhe, Ganjiang,

95 Xinjiang, Raohe, and Xiushui) feeding Poyang Lake and one outlet connecting to Yangtze River

96 (Figure 1). The annual runoff of Poyang Lake is 152.5 billion $\mathrm{m}^{3}$, accounting for $16.3 \%$ annual

97 runoff of Yangtze River. Poyang Lake is a shallow seasonal lake and a typical water-carrying and

98 throughput lake restricted by the water level of Yangtze River and the inflows of the five tributaries

99 (Fang et al, 2011; Zhao et al, 2011). The high and low water levels of Poyang Lake are $20.69 \mathrm{~m}$

100 and $9.82 \mathrm{~m}$ above the sea level, respectively (Liao et al, 2017). The average water depth is $8.4 \mathrm{~m}$

101 (Wang and Liang, 2015). Poyang Lake has been suffering persistent eutrophication (Liao et al,

102 2017). Previous research shown that cyanobacteria blooms have been observed in Poyang Lake

103 since 2000 (Liu et al, 2016b) but only occur periodically and regionally (Liu and Fang, 2017). We

104 didn’t find cyanobacteria bloom during our sampling in early August 2017.

105 We collected samples from Poyang Lake and its tributaries in 10 and 24 sample sites, respectively

106 (Figure 1). In each sample site, a handheld meter (YSI Professional Plus, Yellow Springs, Ohio)

107 was used to measure water temperature (Temp), dissolved oxygen (DO), $\mathrm{pH}$, and conductivity

108 (Cond) in situ. Secchi disk depth (SD) was measured as well. Water samples were collected at the 
109 depth of $0.5 \mathrm{~m}$ using a Van Dorn water sampler. $200 \mathrm{~mL}$ water was filtered onto a $0.2-\mu \mathrm{m}$

110 Polycarbonate Membrane Filter (Whatman, UK), which was immediately frozen in liquid nitrogen

111 in the field and stored at $-80^{\circ} \mathrm{C}$ in the lab until DNA extraction. Another $500 \mathrm{ml}$ water was acid

112 fixed in the field and transported to the laboratory at $4{ }^{\circ} \mathrm{C}$ for chemical analyses. Sediment samples

113 were collected using a Ponar Grab sampler at the depth of 5.5 to $6.5 \mathrm{~m}$ in Poyang Lake and of 3.9

114 to $5.8 \mathrm{~m}$ in the tributaries. The top $5-\mathrm{cm}$ sediment was homogenized by stirring with a spatula,

115 collected in a sterile centrifuge tube, and immediately frozen in liquid nitrogen in the field for

116 DNA extraction. The remaining sediment was collected in a clean Ziploc bag for chemical

117 analyses.

118 For water samples, total nitrogen $(\mathrm{TN})$, nitrate $\left(\mathrm{NO}_{3}^{-}\right)$, ammonium $\left(\mathrm{NH}_{4}^{+}\right)$, total phosphorus (TP),

119 and soluble reactive phosphorus (SRP) were analyzed according to the Clean Water Act Analytical

120 Methods (EPA). DOC was analyzed using a TOC Analyzer (TOC-VCPH, Shimadzu Scientific

121 Instruments). Detailed information of water sample analyses was provided in our previous study

122 (Ren et al, 2019). For sediment samples, TN was analyzed using the modified Kjeldahl method

123 (HJ717-2014). $\mathrm{NO}_{3}{ }^{-}$and $\mathrm{NH}_{4}{ }^{+}$were analyzed using $\mathrm{UV}$ spectrophotometry method (HJ634-2012).

124 TP was analyzed using alkali fusion-Mo-Sb Anti spectrophotometric method (HJ632-2011). Total

125 organic carbon (OC) was analyzed using Potassium dichromate oxidation spectrophotometric

126 method (HJ615-2011). Organic nitrogen (ON) was analyzed using acid hydrolysis method

127 (Bremner, 1965). Organic phosphorus (OP) was analyzed using SMT method (Ruban et al, 1999).

128 DNA extraction, PCR, and sequencing

129 DNA was extracted from the filter and sediment $(0.5 \mathrm{~g})$ samples using the TIANGEN-DP336 soil

130 DNA Kit (TIANGEN-Biotech, Beijing, China) following manufacturer protocols. Extracted DNA

131 samples were quantified using a Qubit 2.0 Fluorometer (Invitrogen, Carlsbad, CA, USA). The V3 
132 and V4 regions were amplified using the forward primer 347F 5'-

133 CCTACGGRRBGCASCAGKVRVGAAT-3' and the reverse primer 802R 5'-

134 GGACTACNVGGGTWTCTAATCC-3' (GENEWIZ, Inc., South Plainfield, NJ, USA) (Ren et al,

135 2019). PCR was performed using the following program: initial denaturation at $94{ }^{\circ} \mathrm{C}$ for 3 min,

13624 cycles of denaturation at $94{ }^{\circ} \mathrm{C}$ for $30 \mathrm{~s}$ followed by annealing at $57{ }^{\circ} \mathrm{C}$ for $90 \mathrm{~s}$ and extension

137 at $72{ }^{\circ} \mathrm{C}$ for $10 \mathrm{~s}$, and final extension step at $72{ }^{\circ} \mathrm{C}$ for $10 \mathrm{~min}$. Amplified DNA was verified by

138 electrophoresis of PCR mixtures in $1.0 \%$ agarose in $1 \mathrm{X}$ TAE buffer and purified using the Gel

139 Extraction Kit (Qiagen, Hilden, Germany). DNA libraries were validated by Agilent 2100

140 Bioanalyzer (Agilent Technologies, Palo Alto, CA, USA), and quantified by Qubit 2.0

141 Fluorometer (Invitrogen, Carlsbad, CA, USA). DNA libraries were multiplexed and loaded on an

142 Illumina MiSeq instrument (Illumina, San Diego, CA, USA) according to manufacturer's

143 instructions.

\section{Sequence analysis and functional gene prediction}

145 Raw sequence data was processed using the software package QIIME 1.9.1 (Caporaso et al, 2010).

146 The forward and reverse reads were joined and assigned to samples based on barcode and truncated

147 by cutting off the barcode and primer sequence. Then the sequences were quality filtered, and the

148 chimeric sequences were removed. Sequences which did not fulfill the following criteria were

149 discarded: sequence length $<200 \mathrm{bp}$, no ambiguous bases, mean quality score $>=20$ (Ren et al,

150 2019). The effective sequences were grouped into operational taxonomic units (OTUs) at 97\%

151 sequence identity level against the Greengenes 13.8 database (Mcdonald et al, 2012). Then the

152 functional potentials of the bacterial communities were predicted using PICRUSt 1.1.0

153 (Phylogenetic Investigation of Communities by Reconstruction of Unobserved States) and the

154 nearest sequence taxon index (NSTI) was calculated to indicate the accuracy of PICRUSt 
155 prediction (Langille et al, 2013). The average NSTI was 0.146, indicating high accuracy (Langille

156 et al, 2013). Then, the predicted metagenomes were further classified into Kyoto Encyclopedia of

157 Genes and Genomes (KEGG) Orthologs (KOs). The KOs associated with carbon, nitrogen, and

158 sulfur metabolism as well as phosphorus cycle were identified from KEGG database (Kanehisa

159 and Goto, 2000; Bergkemper et al, 2016). The Raw sequence data are available at National Center

160 for Biotechnology Information (PRJNA436872, SRP133903).

\section{Statistical analysis}

162 To reveal the functional differences (overall metagenomic functions and the major functions,

163 including carbon metabolism, nitrogen metabolism, phosphorus cycle, and sulfur metabolism)

164 between the bacterial communities in different habitats of the river-lake ecosystem of Poyang

165 Lake, non-metric multidimensional scaling (NMDS) and analysis of variance using distance

166 matrices (ADONIS) were applied using the Vegan package 2.4-6 (Oksanen et al, 2007) based on

167 the relative abundance of KOs. Differences of the major pathways associated to carbon

168 metabolism, nitrogen metabolism, phosphorus cycle, and sulfur metabolism between the bacterial

169 communities in sediment and water column were tested using analysis of variance (ANOVA) and

170 the P-values were adjusted by FDR correction. Linear regression was used to assess the

171 relationships between taxonomic and functional dissimilarities, revealing functional redundancy

172 of the bacterial communities (stronger linear regression indicates lower functional redundancy)

173 (Yang et al, 2017; Galand et al, 2018). Taxonomic and functional dissimilarities were calculated

174 as Bray-Curtis distances based on the phylogenetic and metagenomic compositions (relative

175 abundance of OTUs and KOs, respectively). The differences of linear regression slopes were

176 compared using analysis of covariance (ANCOVA). Distance-based redundancy analysis

177 (dbRDA) was conducted using Vegan package to reveal the relationships between environmental 
178 variables (normalized using "normalize" method) and overall functional compositions (relative

179 abundance of KOs, Hellinger transferred) of bacterial communities in sediment and water column,

180 and the significance of the nutrient variables was tested using Envfit function in R. Mantel tests

181 were applied to assess the relationships between nutrient factors and major functions and the P-

182 values were adjusted by FDR correction. All the analyses were conducted in R 3.4.4 (R Core Team, 183 2017).

184 Results

185 Functional differences

186 In total, 6295 and 6187 KOs were detected in bacterial communities in sediment and water column.

187 Profound differences were detected in functional compositions between sediment and water.

188 NMDS and ADONIS showed that bacterial communities in LS and RS were significantly $(\mathrm{P}<0.05)$

189 different to LW and RW (LS vs. LW and RS vs. RW), respectively (Figure 2). However, there was

190 no difference between Poyang Lake and its tributaries (LS vs. RS and LW vs. RW, Figure 2). For

191 carbon metabolism, we detected 242 KOs associated to central carbon metabolism pathways

192 (ko01200) based on the KEGG database. Carbohydrate metabolism, carbon fixation pathways in

193 prokaryotes, and methane metabolism had a higher relative abundance of associated genes in the

194 bacterial communities in sediment than in water (Figure 3A). However, the lipid metabolism had 195 a higher relative abundance in water than in sediment (Figure 3A). For the nitrogen metabolism, 196 we detected 41 KOs associated to nitrogen metabolism pathways (ko00910 in KEGG database).

197 Bacterial communities had a higher relative abundance of genes associated to anammox and 198 nitrogen fixation in sediment than in water (Figure 3B). However, assimilatory nitrate reduction 199 to ammonia (ANRA) and dissimilatory nitrate reduction to ammonia (DNRA) had a higher relative 200 abundance in water than in sediment (Figure 3B). For phosphorus, we detected 43 KOs associated 
201 to phosphorus cycle. Phosphonate degradation had a higher relative abundance in water than in 202 sediment (Figure 3C). For sulfur metabolism, we detected $45 \mathrm{KOs}$ associated to the sulfur 203 metabolism pathways (ko00920 in KEGG database). Assimilatory sulfate reduction had a lower 204 relative abundance while dissimilatory sulfate reduction had a higher relative abundance in 205 sediment than in water (Figure 3D).

\section{Environmental influences}

207 The results of dbRDA indicated that the overall functional compositions of bacterial communities 208 in sediment were significantly correlated with $\mathrm{TP}$ and $\mathrm{NO}_{3}^{-}$(Figure 4A). The first two axes 209 explained $31.85 \%$ of the functional variation (dbRDA 1: 19.21\%; dbRDA 2: 12.64\%). For the

210 bacterial communities in water column, the overall functional compositions were significantly

211 correlated with TN, $\mathrm{NO}_{3}{ }^{-}$, TP, TN:TP, DOC:DIN, DIN:SRP, as well as Cond, Temp, DO, and $\mathrm{pH}$

212 (Figure 4B). The first two axes explained $67.03 \%$ of the functional variation (dbRDA 1: 47.79\%;

213 dbRDA 2: 19.24\%). Mantel tests further demonstrated that the spatial variations of the major

214 biogeochemical processes (C-metabolism, N-metabolism, P-cycle, and S-metabolism) were

215 significantly influenced by $\mathrm{TP}$ and $\mathrm{NO}_{3}{ }^{-}$in sediment, and by TN, TP, SRP, DOC:DIN, and 216 DOC:SRP in water column (Figure 5).

\section{Functional redundancy}

218 Linear regressions between taxonomic and functional dissimilarities showed that the variations in 219 metagenomic functional composition (overall, C-metabolism, N-metabolism, P-cycle, and S220 metabolism) were closely associated with the variations in phylogenetic composition (Figure 6).

221 However, sediment bacterial communities had significantly smaller slopes than bacterial 222 communities in water column (ANCOVA, $\mathrm{P}<0.05$, Figure $6 \mathrm{~F}$ ). For the major functions in 223 sediment, nitrogen metabolism had a higher slope, followed by sulfur metabolism, carbon 
224 metabolism, and phosphorus cycle (Figure 6). In water column, however, nitrogen metabolism and

225 phosphorus cycle had higher slopes than carbon and sulfur metabolisms (Figure 6). The results

226 suggested that bacterial communities in sediment had higher functional redundancy than in water

227 column. Moreover, bacterial communities had lowest functional redundancy for nitrogen

228 metabolism but highest functional redundancy for phosphorus cycle in sediment, while had lowest

229 redundancy for both nitrogen metabolism and phosphorus cycle in water column.

230 Discussion

231 In this study, the functional composition of bacterial communities in the river-lake system of

232 Poyang Lake were different between water and sediment (LS vs. LW and RS vs. RW), while no

233 different between tributaries and the lake itself (LS vs. RS and LW vs. RW). In our previous study

234 of the river-lake system of Poyang Lake (Ren et al, 2019), bacterial communities were

235 taxonomically different between sediment and water. It has been well demonstrated that sediment

236 and water had distinct bacterial communities (Jiang et al, 2006; Nishihama et al, 2008; Lu et al,

237 2016), which might determine significant functional differences (Fierer et al, 2012; Ren et al,

238 2017a). However, the taxonomical differences of bacterial communities between Poyang Lake and

239 its tributaries were significant but smaller compared to the differences between sediment and water

240 (Ren et al, 2019). In generally, bacterial communities were more taxonomically different than

241 functional different (Louca et al, 2017; Ren et al, 2017a). Thus, the small differences in taxonomic

242 composition of bacterial communities did not lead to their functional differences between Poyang

243 Lake and its tributaries.

244 This study showed that carbohydrate metabolism, carbon fixation pathways in prokaryotes, and

245 methane metabolism had a higher relative abundance in the bacterial communities in sediment

246 than in water, and the lipid metabolism had a higher relative abundance in water than in sediment. 
247 The results suggested that bacterial communities in sediment and water had distinct carbon

248 metabolism pathways. Organic matter (OM) transported by river provides fueling aquatic food

249 webs as a major source of energy and is also a significant component of the global carbon cycle

250 (Cole et al, 2007; Battin et al, 2008; Smith and Kaushal, 2015). In freshwater ecosystems, OM is

251 a heterogeneous mixture including allochthonous materials contributed by soil and plant litter

252 inputs from terrestrial ecosystems and autochthonous materials contributed by primary producers

253 in freshwater ecosystems (Webster and Meyer, 1997). OM is consisted of carbohydrates, proteins,

254 lipids, lignins, and other compounds in aquatic ecosystems (Thurman, 2012). Microorganisms are

255 key biogeochemical agents in the generation, transformation, and mineralization of OM (Horvath,

256 1972).Variations of OM in its source and composition, as well as the bioavailability of its

257 components determine the spatial patterns of bacterial composition and functional diversity

258 (Hoostal and Bouzat, 2008; Wang et al, 2018). In aquatic ecosystems, sediment and water column

259 have distinct redox environments (Roeske et al, 2012), and the OM derives from different sources

260 with different compositions (Hedges et al, 1988). These differences might lead to the distinct

261 carbon metabolisms between water and sediment. For example, the reduction condition in

262 sediment is benefit to methane production (Koyama, 1963; He et al, 2015; Liu and Xu, 2016). In

263 sediment, methane-oxidizing and sulfate-reducing bacteria also play the roles in carbon fixation

264 (Kellermann et al, 2012).

265 Our study also showed that sediment and water column were significantly different in nitrogen

266 metabolism, suggesting different nitrogen use strategies. In the past century, the nitrogen entering

267 freshwater ecosystem has been increased more than two-fold by anthropogenic activities

268 (Schlesinger, 2009; Meunier et al, 2016), contributing to eutrophication in lake and coastal

269 ecosystems (Nixon, 1995; Smith, 2003). Poyang Lake has been facing serious threat of 
270 eutrophication (Wang et al, 2015; Zhang et al, 2015; Liu et al, 2016a) because of the aggravated

271 nutrient loading from agriculture and urbanization of the catchment in recent decades (Wang and

272 Liang, 2015; Liu et al, 2016a). Nitrogen has many different chemical forms from the oxidation

273 state of nitrate $(+5)$ to the reduction state of ammonia $(-3)$ and is cycled by a suite of

274 biogeochemical processes (Ollivier et al, 2011), including four reduction pathways

275 (denitrification, nitrogen fixation, ANRA, and DNRA) and two oxidation pathway (anammox and 276 nitrification) (Lamba et al, 2017).. In aquatic ecosystems, denitrification is the main biological

277 process turning nitrate to dinitrogen and nitrous oxide (Tiedje et al, 1983; Seitzinger, 1988) and

278 anammox is another important pathway turning nitrite and ammonia to dinitrogen (Dalsgaard et

279 al, 2003; Kuypers et al, 2003). Both denitrification and anammox play important roles in removing

280 nitrogen from aquatic ecosystems. In our study, bacterial communities in both sediment and water

281 had a high relative abundance of the genes associated to denitrification, suggesting strong

282 potentials in nitrogen removal. Many previous studies have demonstrated that rivers and lakes are

283 hot spots to remove $\mathrm{N}$ inputs to surface waters from terrestrial environments (Wollheim et al, 2008;

284 Harrison et al, 2009; Beaulieu et al, 2011). Denitrification can be limited by the supply of $\mathrm{NO}_{3}{ }^{-}$

285 and OC, as well as redox potential (Van Kessel, 1977; Seitzinger, 1988). Furthermore, nitrification

286 is also an important process in the $\mathrm{N}$ cycle and couples with denitrification (Jenkins and Kemp,

287 1984; Nils, 2003), especially in the shallow lakes. In the eutrophic river-lake system of Poyang

288 Lake, the high contents of $\mathrm{OM}$ and $\mathrm{NO}_{3}{ }^{-}$in water and sediment can facilitate denitrification.

289 Moreover, the respiration in sediment can provide an anoxic environment and promote sediment

290 denitrification. On the other hand, it has also been supported by many studies that aerobic

291 denitrification can be performed by a broad range of bacterial organisms under an aerobic

292 environment (Ji et al, 2015; Lv et al, 2017). In our study, the high potential denitrification (potential 
$293 \mathrm{NO}_{3}{ }^{-}$reductions) in water might be performed through aerobic denitrification with the facilitation

294 of high supplement of $\mathrm{OM}$ and $\mathrm{NO}_{3}{ }^{-}$. In addition to denitrification, bacterial communities in

295 sediment had a significantly higher relative abundance of the genes associated to anammox than

296 in water. It was found that anammox can coupled to nitrate reduction to contribute substantially to

297 produce dinitrogen in sediments (Thamdrup and Dalsgaard, 2002). These results suggested that

298 the bacterial communities in water and sediment of this eutrophic river-lake system had strong

299 functional potentials but different strategies in nitrogen removal. In contrast to nitrogen removal,

300 bacterial communities in sediment also had a higher relative abundance of genes associated with

301 nitrogen fixation. In fact, the genetic potential of nitrogen fixation is pervasive among the domains

302 of Bacteria and Archaea (Zehr et al, 2003). Nitrogen fixation and denitrification can co-occur in

303 sediments through heterotrophic nitrogen fixation (Newell et al, 2016). We have underestimated

304 the importance of heterotrophic sediment nitrogen fixation in the past, which can be an important

305 source of nitrogen even under higher inorganic nitrogen concentrations (Fulweiler and Heiss,

306 2014; Newell et al, 2016). Examining the expression of the genes encoding for nitrogenase (such

307 as nifD, nifH, nifK, and anfG) in the bacterial communities can help us understand the nitrogen

308 fixation potential in freshwater ecosystems. In our study, the high relative abundance of genes

309 associated to nitrogen fixation suggested a significant nitrogen fixation potential in sediment in

310 Poyang Lake and its tributaries. In nitrogen metabolism pathways, both ANRA and DNRA had a

311 higher relative abundance in water than in sediment, suggesting strong potentials of nitrate

312 reduction to ammonia for bacterial communities in water column. ANRA and DNRA serve distinct

313 cellular functions (Lamba et al, 2017): ANRA consumes energy and provides ammonium for cell

314 to synthesize amino acids and nucleotides, while NDRA generates ATP in absence of oxygen and

315 retains the nitrogen in the form of $\mathrm{NH}_{4}^{+}$for further biological processes (Zumft, 1997). 
316 Phosphorus is an essential element in all ecosystems used by all living organisms. Bacteria plays

317 a pivotal role in natural phosphorus cycles on the earth (Ohtake et al, 1996; Kononova and

318 Nesmeyanova, 2002). In this study, the results showed that phosphonate degradation had a higher

319 relative abundance in water than in sediment. Phosphonates are characterized by direct carbon-to-

320 phosphorus bonds, which are resistant to chemical hydrolysis and thermal degradation (Ohtake et

321 al, 1996; Kononova and Nesmeyanova, 2002). In polluted freshwater ecosystems, large quantities

322 of phosphonates are xenobiotics, such as pesticides, antibiotics, and detergent additives

323 (Schowanek and Verstraete, 1990). It has been revealed that phosphonates are significantly

324 removed from marine basin due to rapid release and remineralization (Benitez-Nelson et al, 2004).

325 Our study suggested that bacterial communities in water column are important in phosphonates

326 removal.

327 For sulfur metabolism in the eutrophic river-lake system of Poyang Lake, our study showed that

328 the assimilatory reduction is more common than dissimilatory reduction and the bacterial

329 communities in water had a higher assimilatory sulfur reduction potential while lower

330 dissimilatory sulfate reduction than in sediment. Sulfur is an important element required for some

331 cellular components related to proteins. In the sulfur metabolism of bacteria, assimilatory sulfate

332 reduction commences with the incorporation of sulfide radical for the biosynthetic cycle. Thus,

333 during assimilatory sulfate reduction, there is no sulfide produced. For some microorganisms,

334 sulfur compounds are utilized in dissimilatory and energy-yielding metabolic processes, which

335 takes place in anaerobic respiration. During dissimilatory sulfate reduction, sulfate ion is used as

336 the terminal electron acceptor and is reduced to produce sulfide, in the meantime, organic carbon

337 is mineralized with producing of carbon dioxide. In lake sediments, dissimilatory sulfate reduction

338 can account for a significant fraction of organic carbon mineralization, especially in eutrophic 
339 lakes with high availabilities of organic matter and sulfate (Holmer and Storkholm, 2001). The

340 differences of sulfur metabolism between water and sediment shed light on sulfur use strategies of

341 bacterial communities in these two distinct habitats.

342 As discussed above, biogeochemical cycles of C, N, P, and S are important ecological functions

343 in freshwater ecosystems. In our study, mantel tests showed significant correlations between

344 taxonomic and functional dissimilarity matrixes (beta diversities), suggesting that the overall

345 changes in potential functions, as well as the changes of potential metabolisms of C, N, P, and S

346 were closely associated with changes in taxonomic compositions of the bacterial communities.

347 Functional redundancy always exists in natural ecosystems (Cardinale et al, 2000; Rosenfeld,

348 2002; Allison and Martiny, 2008) and is measured by the correlation between taxonomic and

349 functional gene diversities (Fierer et al, 2013; Yang et al, 2017). Functional redundancy occurs

350 when different organisms execute a similar function, remaining functional stabilization of

351 communities upon species loss (Rosenfeld, 2002; Nystrom, 2006). Our results showed that the

352 bacterial communities in water column had a lower redundancy of overall functions than in

353 sediment. Moreover, compared to overall functions, sediment bacterial communities had lower

354 functional redundancy of $\mathrm{N}$ metabolism, and bacterial communities in water column had lower

355 functional redundancy of $\mathrm{N}$ metabolism and $\mathrm{P}$ cycle. In bacterial communities, functional

356 redundancy is expected to allow bacterial communities to have a certain extent of resistance and

357 resilience in facing environmental perturbations (Allison and Martiny, 2008; Bowen et al, 2011).

358 The results suggested that the bacterial communities in water column were less stable than

359 bacterial communities in sediment. Moreover, $\mathrm{N}$ metabolism and P cycle was more vulnerable to

360 environmental perturbations than $\mathrm{C}$ and $\mathrm{S}$ metabolisms, influencing nutrient biogeochemical

361 processes in the eutrophic river-lake system of Poyang Lake. 


\section{Conclusions}

363 In this study, we assessed the functional properties of bacterial communities in lake sediment, river

364 sediment, lake water, and river water in the river-lake system of Poyang Lake. In general, the

365 results showed that bacterial communities in sediment and water had distinct potential functions

366 in the biogeochemical processes of carbon, nitrogen, phosphorus, and sulfur. However, there was

367 no difference between tributaries and the lake itself. Moreover, bacterial communities in water

368 column had a lower functional redundancy than in sediment. Comparing to the overall functions

369 within systems, bacterial communities had lower functional redundancy of nitrogen metabolism

370 in sediment, and lower functional redundancy of nitrogen metabolism and phosphorus cycle in

371 water column. In this eutrophic river-lake system, functional compositions of the bacterial

372 communities were vulnerable to nutrient perturbations especially in water column. By revealing

373 the metabolism pathways of major functions, the influences of nutrient variables on functional

374 compositions, and functional redundancy, this study can provide insights into the microbial

375 community structures and ecological processes in this river-lake system.

\section{Conflict of Interest Statement}

377 The authors declare no competing interests.

\section{Acknowledgements}

379 We are grateful to the anonymous reviewers for the comments, to Yuhang Zhang and Chenyu

380 Yang for their assistances in the field and laboratory work. 


\section{Figure Legends}

382 Figure 1 Study area and sampling sites. Samples were collected from the surface water and

383 sediment of Poyang lake and its fiver tributaries (Xiushui, Ganjiang, Fuhe, Xinjiang, and Raohe).

384 This figure was modified from Ren et al, 2019.

385 Figure 2 Functional differences between habitats. (A-E) Non-metric multidimensional scaling 386 analysis of potential functions composition in terms of overall functions, carbon metabolism, 387 nitrogen metabolism, phosphorus cycle, and sulfur metabolism. (F) Pairwise dissimilarity tests of 388 functional composition between different habitats using ADONIS. The numbers outside the 389 bracket are " $\mathrm{R}^{2}$ ". P-values are in bracket.

390 Figure 3 Relative abundance of genes associated to major pathways in (A) central carbon 391 metabolism, (B) nitrogen metabolism, (C) phosphorus cycle, and (D) sulfur metabolism. For each 392 pathway, the same lowercase letter indicates a non-significant difference, whereas the different 393 letter indicates a significant difference between habitats (ANOVA, $\mathrm{P}<0.05$ ). P-values were 394 adjusted by FDR correction.

395 Figure 4 Biplot of distance-based redundancy analyses (dbRDA) showing the relationship between

396 functional composition and nutrient variables in (A) sediment and (B) water. The red arrows 397 represent the significant variables (envfit, $\mathrm{P}<0.05$ ).

398 Figure 5 Mantel tests between major functions and nutrient variables of (A) sediment and (B) water

399 based on Spearman correlation. Significant correlations $(\mathrm{P}<0.05)$ were colored. P-values were 400 adjusted by FDR correction. 
401 Figure 6 (A-E) Linear regressions between taxonomic and functional dissimilarities. One point 402 represents one sample pair. Shadow area denotes the 95\% confidence interval. (F-G) Statistical 403 test of the linear regression slopes between systems and within systems using ANCOVA.

404

405 References

Allison SD, Martiny JBH. 2008. Resistance, resilience, and redundancy in microbial communities. Proceedings of the National Academy of Sciences of the United States of America 1051: 1151211519.

Barberan A, Fernandez-Guerra A, Bohannan BJM, Casamayor EO. 2012. Exploration of community traits as ecological markers in microbial metagenomes. Molecular Ecology 21: 1909-1917.

Battin TJ, Kaplan LA, Findlay S, Hopkinson CS, Marti E, Packman AI, Newbold JD, Sabater F. 2008. Biophysical controls on organic carbon fluxes in fluvial networks. Nature Geoscience 1:

$$
95-100
$$

Beaulieu JJ, Tank JL, Hamilton SK, Wollheim WM, Hall RO, Mulholland PJ, Peterson BJ, Ashkenas LR, Cooper LW, Dahm CN, Dodds WK, Grimm NB, Johnson SL, Mcdowell WH, Poole GC, Valett HM, Arango CP, Bernot MJ, Burgin AJ, Crenshaw CL, Helton AM, Johnson LT, O'Brien JM, Potter JD, Sheibley RW, Sobota DJ, Thomas SM. 2011. Nitrous oxide emission from denitrification in stream and river networks. Proceedings of the National Academy of Sciences 108: 214-219. 
421 Benitez-Nelson CR, O'Neill L, Kolowith LC, Pellechia P, Thunell R. 2004. Phosphonates and

422 Particulate Organic Phosphorus Cycling in an Anoxic Marine Basin. Limnology and 423 Oceanography 49: 1593-1604.

424 Bergkemper F, Schöler A, Engel M, Lang F, Krüger J, Schloter M, Schulz S. 2016. Phosphorus 425 depletion in forest soils shapes bacterial communities towards phosphorus recycling systems. 426 Environmental Microbiology 18: 1988-2000.

427 Bowen JL, Ward BB, Morrison HG, Hobbie JE, Valiela I, Deegan LA, Sogin ML. 2011. Microbial 428 community composition in sediments resists perturbation by nutrient enrichment. ISME $429 \quad$ Journal 5: 1540-1548.

430 Bremner JM. 1965. Organic forms of nitrogen. In: Method of soil analysis. Part II, Black CA et al. 431 Eds., American Society of Agronomy, Madison, Wisconsin, USA.

432 Briee C, Moreira D, Lopez-Garcia P. 2007. Archaeal and bacterial community composition of 433 sediment and plankton from a suboxic freshwater pond. Research in Microbiology 158: 213434227.

435 Caporaso JG, Kuczynski J, Stombaugh J, Bittinger K, Bushman FD, Costello EK, Fierer N, Pena 436 AG, Goodrich JK, Gordon JI, Huttley GA, Kelley ST, Knights D, Koenig JE, Ley RE, 437 Lozupone CA, Mcdonald D, Muegge BD, Pirrung M, Reeder J, Sevinsky JR, Tumbaugh PJ, 438 Walters WA, Widmann J, Yatsunenko T, Zaneveld J, Knight R. 2010. QIIME allows analysis 439 of high-throughput community sequencing data. Nature Methods 7: 335-336.

440 Cardinale BJ, Nelson K, Palmer MA. 2000. Linking species diversity to the functioning of 441 ecosystems: on the importance of environmental context. Oikos 91: 175-183. 
442 Cole JJ, Carpenter SR, Pace ML, Van de Bogert MC, Kitchell JL, Hodgson JR. 2006. Differential 443 support of lake food webs by three types of terrestrial organic carbon. Ecology Letters 9: 558444568.

445 Cole JJ, Prairie YT, Caraco NF, Mcdowell WH, Tranvik LJ, Striegl RG, Duarte CM, Kortelainen 446 P, Downing JA, Middelburg JJ, Melack J. 2007. Plumbing the Global Carbon Cycle: 447 Integrating Inland Waters into the Terrestrial Carbon Budget. Ecosystems 10: 172 - 185.

448 Cotner JB, Biddanda BA. 2002. Small players, large role: Microbial influence on biogeochemical 449 processes in pelagic aquatic ecosystems. Ecosystems 5: 105-121.

450 Dalsgaard T, Canfield DE, Petersen J, Thamdrup B, Acuna-Gonzalez J. 2003. N-2 production by 451 the anammox reaction in the anoxic water column of Golfo Dulce, Costa Rica. Nature 422: $452 \quad 606-608$.

453 Dopheide A, Lear G, He Z, Zhou J, Lewis GD. 2015. Functional Gene Composition, Diversity and 454 Redundancy in Microbial Stream Biofilm Communities. PLoS One 10.

455 EPA. Clean Water Act Analytical Methods. https://www.epa.gov/cwa-methods.

456 Fang C, Lai Z, Yang J, Xu Y. 2011. Study on the Nonuniform Spatial Distribution of Water Level 457 in Poyang Lake Based on ASAR Images and DEM. Procedia Environmental Sciences 10: $458 \quad 2540-2546$.

459 Fierer N, Ladau J, Clemente JC, Leff JW, Owens SM, Pollard KS, Knight R, Gilbert JA, Mcculley 460 RL. 2013. Reconstructing the microbial diversity and function of pre-agricultural tallgrass 461 prairie soils in the United States. Science 342: 621-624.

462 Fierer N, Leff JW, Adams BJ, Nielsen UN, Bates ST, Lauber CL, Owens S, Gilbert JA, Wall DH, 463 Caporaso JG. 2012. Cross-biome metagenomic analyses of soil microbial communities and 
464 their functional attributes. Proceedings of the National Academy of Sciences of the United $465 \quad$ States of America 109: 21390-21395.

466 Freedman ZB, Zak DR. 2015. Atmospheric N deposition alters connectance, but not functional 467 potential among saprotrophic bacterial communities. Molecular Ecology 24: 3170-80.

468 Fulweiler RW, Heiss EM. 2014. (Nearly) A Decade of Directly Measured Sediment N-2 Fluxes 469 What Can Narragansett Bay Tell Us About the Global Ocean Nitrogen Budget? Oceanography $470 \quad$ 27: $184-195$.

471 Galand PE, Pereira O, Hochart C, Auguet JC, Debroas D. 2018. A strong link between marine 472 microbial community composition and function challenges the idea of functional redundancy. 473 ISME Journal 12: 2470-2478.

474 Green JL, Bohannan BJM, Whitaker RJ. 2008. Microbial biogeography: From taxonomy to traits. $475 \quad$ Science 320: 1039-1043.

476 Harrison JA, Maranger RJ, Alexander RB, Giblin AE, Jacinthe P, Mayorga E, Seitzinger SP, 477 Sobota DJ, Wollheim WM. 2009. The regional and global significance of nitrogen removal in $478 \quad$ lakes and reservoirs. Biogeochemistry 93: 143-157.

479 He R, Wooller MJ, Pohlman JW, Tiedje JM, Leigh MB. 2015. Methane-derived carbon flow 480 through microbial communities in arctic lake sediments. Environmental Microbiology 17: $481 \quad 3233-3250$.

482 Hedges JI, Clark WA, Come GL. 1988. Organic matter sources to the water column and surficial 483 sediments of a marine bay. Limnology and Oceanography 33: 1116-1136.

484 Holmer M, Storkholm P. 2001. Sulphate reduction and sulphur cycling in lake sediments: a review. 485 Freshwater Biology 46: 431-451. 
486 Hoostal MJ, Bouzat JL. 2008. The modulating role of dissolved organic matter on spatial patterns

487 of microbial metabolism in Lake Erie sediments. Microbial Ecology 55: 358-68.

488 Horvath RS. 1972. Microbial co-metabolism and the degradation of organic compounds in nature.

489 Bacteriological Reviews 36: 146-155.

490 Huang X, Hu B, Wang P, Chen X, Xu B. 2016. Microbial diversity in lake-river ecotone of Poyang $491 \quad$ Lake, China. Environmental Earth Sciences 75: 1-7.

492 Hupfer M, Lewandowski J. 2008. Oxygen Controls the Phosphorus Release from Lake Sediments 493 - a Long-Lasting Paradigm in Limnology. International Review of Hydrobiology 93: 415-432. 494 Jenkins MC, Kemp WM. 1984. The Coupling of Nitrification and Denitrification in Two Estuarine 495 Sediments. Limnology and Oceanography 29: 609-619.

496 Ji B, Yang K, Zhu L, Jiang Y, Wang H, Zhou J, Zhang H. 2015. Aerobic denitrification: A review 497 of important advances of the last 30 years. Biotechnology and Bioprocess Engineering 20: 643$498 \quad 651$.

499 Jiang H, Dong H, Zhang G, Yu B, Chapman LR, Fields MW. 2006. Microbial diversity in water 500 and sediment of Lake Chaka, an athalassohaline lake in northwestern China. Appl Environ $501 \quad$ Microbiol 72: 3832-45.

502 Jones NE. 2010. Incorporating lakes within the river discontinuum: longitudinal changes in 503 ecological characteristics in stream-lake networks. Canadian Journal of Fisheries and Aquatic $504 \quad$ Sciences 67: 1350-1362.

505 Kanehisa M, Goto S. 2000. KEGG: kyoto encyclopedia of genes and genomes. Nucleic Acids $506 \quad$ Research 28: 27-30.

507 Kellermann MY, Wegener G, Elvert M, Yoshinaga MY, Lin YS, Holler T, Mollar XP, Knittel K, 508 Hinrichs KU. 2012. Autotrophy as a predominant mode of carbon fixation in anaerobic 
methane-oxidizing microbial communities. Proceedings of the National Academy of Sciences,

$510 \quad$ 109: 19321-193216.

511 Kononova SV, Nesmeyanova MA. 2002. Phosphonates and their degradation by microorganisms.

512 Biochemistry (Moscow) 67: 184-195.

513 Koyama T. 1963. Gaseous metabolism in lake sediments and paddy soils and the production of 514 atmospheric methane and hydrogen. Journal of Geophysical Research 68: 3971-3973.

515 Kuypers M, Sliekers AO, Lavik G, Schmid M, Jorgensen BB, Kuenen JG, Damste J, Strous M, 516 Jetten M. 2003. Anaerobic ammonium oxidation by anammox bacteria in the Black Sea. Nature $517 \quad$ 422: 608-611.

518 Lamba S, Bera S, Rashid M, Medvinsky AB, Sun G, Acquisti C, Chakraborty A, Li B. 2017.

519 Organization of biogeochemical nitrogen pathways with switch-like adjustment in fluctuating $520 \quad$ soil redox conditions. Royal Society Open Science 4: 160768.

521 Langille MGI, Zaneveld J, Caporaso JG, Mcdonald D, Knights D, Reyes JA, Clemente JC, 522 Burkepile DE, Thurber RLV, Knight R, Beiko RG, Huttenhower C. 2013. Predictive functional 523 profiling of microbial communities using $16 \mathrm{~S}$ rRNA marker gene sequences. Nature $524 \quad$ Biotechnology 31: 814-821.

525 Liao M, Yu G, Guo Y. 2017. Eutrophication in Poyang Lake (Eastern China) over the Last 300 526 Years in Response to Changes in Climate and Lake Biomass. PLoS One 12: e01693191.

527 Liu J, Fang S. 2017. Comprehensive evaluation of the potential risk from cyanobacteria blooms in 528 Poyang Lake based on nutrient zoning. Environmental Earth Sciences 76: 342.

529 Liu J, Fang S, Sun J. 2016a. Nutrient zoning of Poyang Lake based on aquatic eco-environment $530 \quad$ indices. Environmental Earth Sciences 75: 1-12. 
531 Liu L, Xu M. 2016. Microbial biomass in sediments affects greenhouse gas effluxes in Poyang

532 Lake in China. Journal of Freshwater Ecology 31: 109-121.

533 Liu W, Yao L, Jiang X, Guo L, Cheng X, Liu G. 2018. Sediment denitrification in Yangtze lakes

534 is mainly influenced by environmental conditions but not biological communities. Science of 535 the Total Environment 616-617: 978-987.

536 Liu X, Li Y, Liu B, Qian K, Chen Y, Gao J. 2016b. Cyanobacteria in the complex river-connected 537 Poyang Lake: horizontal distribution and transport. Hydrobiologia 768: 95-110.

538 Llorens-Marès T, Yooseph S, Goll J, Hoffman J, Vila-Costa M. 2015. Connecting biodiversity and 539 potential functional role in modern euxinic environments by microbial metagenomics. ISME 540 Journal 9: 1648-1661.

541 Louca S, Jacques SMS, Pires APF, Leal JS, Srivastava DS, Parfrey LW, Farjalla VF, Doebeli M. 542 2017. High taxonomic variability despite stable functional structure across microbial $543 \quad$ communities. Nature Ecology \& Evolution 1: 0015.

544 Lozupone CA, Knight R. 2007. Global patterns in bacterial diversity. Proceedings of the National 545 Academy of Sciences of the United States of America 104: 11436-11440.

546 Lu S, Sun Y, Zhao X, Wang L, Ding A, Zhao X. 2016. Sequencing Insights into Microbial 547 Communities in the Water and Sediments of Fenghe River, China. Archives of Environmental $548 \quad$ Contamination and Toxicology 71: 122-132.

549 Lv P, Luo J, Zhuang X, Zhang D, Huang Z, Bai Z. 2017. Diversity of culturable aerobic 550 denitrifying bacteria in the sediment, water and biofilms in Liangshui River of Beijing, China. $551 \quad$ Scientific Reports 7: 10032. 
552 Mackelprang R, Waldrop MP, Deangelis KM, David MM, Chavarria KL, Blazewicz SJ, Rubin

553 EM, Jansson JK. 2011. Metagenomic analysis of a permafrost microbial community reveals a 554 rapid response to thaw. Nature 480: $368-371$.

555 Marcarelli AM, Wurtsbaugh WA. 2009. Nitrogen fixation varies spatially and seasonally in linked $556 \quad$ stream-lake ecosystems. Biogeochemistry 94: 95-110.

557 Mcdonald D, Price MN, Goodrich J, Nawrocki EP, Desantis TZ, Probst A, Andersen GL, Knight 558 R, Hugenholtz P. 2012. An improved Greengenes taxonomy with explicit ranks for ecological 559 and evolutionary analyses of bacteria and archaea. ISME Journal 6: 610-618.

560 Meunier CL, Gundale MJ, Sanchez IS, Liess A. 2016. Impact of nitrogen deposition on forest and 561 lake food webs in nitrogen-limited environments. Glob Chang Biol 22: 164-179.

562 Newell SE, Pritchard KR, Foster SQ, Fulweiler RW. 2016. Molecular evidence for sediment 563 nitrogen fixation in a temperate New England estuary. PeerJ 4: e1615.

564 Newton RJ, Jones SE, Eiler A, Mcmahon KD, Bertilsson S. 2011. A Guide to the Natural History 565 of Freshwater Lake Bacteria. Microbiology and Molecular Biology Reviews 75: 14-49.

566 Nielsen JL, Klausen C, Nielsen PH, Burford M, Jorgensen N. 2006. Detection of activity among 567 uncultured Actinobacteria in a drinking water reservoir. Fems Microbiology Ecology 55: 432$568 \quad 438$.

569 Nils RP. 2003. Coupled Nitrification-Denitrification in Autotrophic and Heterotrophic Estuarine 570 Sediments: On the Influence of Benthic Microalgae. Limnology and Oceanography 48: 93-105.

571 Nishihama S, Haraguchi A, Kawano T, Michiki K, Nakazawa K, Suzuki T, Uezu K, Yoshizuka 572 K. 2008. Seasonal changes in the microbial population of the water column and sediments of 573 the Ongagawa River, northern Kyushu, Japan. Limnology 9: 35-45. 
574 Nixon SW. 1995. Coastal marine eutrophication: A definition, social causes, and future concerns.

575 Ophelia 41: 199-219.

576 Nystrom M. 2006. Redundancy and response diversity of functional groups: Implications for the 577 resilience of coral reefs. Ambio 35: 30-35.

578 Ohtake H, Wu H, Imazu K, Anbe Y, Kato J, Kuroda A. 1996. Bacterial phosphonate degradation, 579 phosphite oxidation and polyphosphate accumulation. Resources, Conservation \& Recycling $580 \quad$ 18: $125-134$.

581 Oksanen J, Kindt R, Legendre PO, Hara B, Stevens MHH, Oksanen MJ, Suggests MASS. 2007.

582 The vegan package. Community Ecology Package 10: 631-637.

583 Ollivier J, Towe S, Bannert A, Hai B, Kastl EM, Meyer A, Su MX, Kleineidam K, Schloter M.

584 2011. Nitrogen turnover in soil and global change. Fems Microbiology Ecology 78: 3-16.

585 Parker SR, West RF, Boyd ES, Feyhl-Buska J, Gammons CH, Johnston TB, Williams GP, Poulson

586 SR. 2016. Biogeochemical and microbial seasonal dynamics between water column and 587 sediment processes in a productive mountain lake: Georgetown Lake, MT, USA. Journal of 588 Geophysical Research-Biogeosciences 121: 2064-2081.

589 Philippot L, Andersson SGE, Battin TJ, Prosser JI, Schimel JP, Whitman WB, Hallin S. 2010. The 590 ecological coherence of high bacterial taxonomic ranks. Nature Reviews Microbiology 8: 523591529.

592 R Core Team. 2017. R: A Language and Environment for Statistical Computing, R Foundation for 593 Statistical Computing, Vienna, Austria. https://www.R-project.org.

594 Ren Z, Gao HK, Elser JJ, Zhao QD. 2017b. Microbial functional genes elucidate environmental 595 drivers of biofilm metabolism in glacier-fed streams. Scientific Reports 7: e12668. 
596 Ren Z, Qu XD, Peng WQ, Yu Y, Zhang M. 2019. Nutrients drive the structures of bacterial 597 communities in sediments and surface waters in the river-lake system of Poyang Lake. Water $598 \quad$ 11: e930.

599 Ren Z, Wang F, Qu XD, Elser JJ, Liu Y, Chu LM. 2017a. Taxonomic and functional differences 600 between microbial communities in Qinghai Lake and its input streams. Frontiers in $601 \quad$ Microbiology 8: 2319.

602 Roeske K, Sachse R, Scheerer C, Roeske I. 2012. Microbial diversity and composition of the 603 sediment in the drinking water reservoir Saidenbach (Saxonia, Germany). Systematic and 604 Applied Microbiology 35: 35-44.

605 Rosenfeld JS. 2002. Functional redundancy in ecology and conservation. Oikos 98: 156-162.

606 Ruban V, Lopez-Sanchez JF, Pardo P, Rauret G, Muntau H, Quevauviller P. 1999. Selection and 607 evaluation of sequential extraction procedures for the determination of phosphorus forms in 608 lake sediment. Journal of Environmental Monitoring 1: 51-56.

609 Schlesinger WH. 2009. On the fate of anthropogenic nitrogen. Proceedings of the National 610 Academy of Sciences of the United States of America 106: 203-208.

611 Schowanek D, Verstraete W. 1990. Phosphonate utilization by bacterial cultures and enrichments 612 from environmental samples. Applied and Environmental Microbiology 56: 895-903.

613 Seitzinger SP. 1988. Denitrification in freshwater and coastal marine ecosystems: ecological and 614 geochemical significance. Limnology and Oceanography 33: 702-724.

615 Smith RM, Kaushal SS. 2015. Carbon cycle of an urban watershed: exports, sources, and 616 metabolism. Biogeochemistry 126: 173-195.

617 Smith VH. 2003. Eutrophication of freshwater and coastal marine ecosystems - A global problem. 618 Environmental Science and Pollution Research 10: 126-139. 
619 Thamdrup B, Dalsgaard T. 2002. Production of N-2 through anaerobic ammonium oxidation 620 coupled to nitrate reduction in marine sediments. Applied and Environmental Microbiology 68: $621 \quad 1312-1318$.

622 Thurman EM. 2012. Organic geochemistry of natural waters (Vol. 2). Springer Science \& Business 623 Media.

624 Tiedje JM, Sexstone AJ, Myrold DD, Robinson JA. 1983. Denitrification: ecological niches, 625 competition and survival. Antonie van Leeuwenhoek 48: 569-583.

626 van der Heijden MGA, Bardgett RD, van Straalen NM. 2008. The unseen majority: soil microbes 627 as drivers of plant diversity and productivity in terrestrial ecosystems. Ecology Letters 11: 296$628 \quad 310$.

629 Van Kessel JF. 1977. Factors affecting the denitrification rate in two water sediment systems. $630 \quad$ Water Research 11: 259-267.

631 Wang J, Zhang Y, Yang F, Cao X, Bai Z, Zhu J, Chen E, Li Y, Ran Y. 2015. Spatial and temporal 632 variations of chlorophyll-a concentration from 2009 to 2012 in Poyang Lake, China. 633 Environmental Earth Sciences 73: 4063-4075.

634 Wang K, Zou L, Lu X, Mou X. 2018. Organic carbon source and salinity shape sediment bacterial 635 composition in two China marginal seas and their major tributaries. Science of the Total 636 Environment 633: 1510-1517.

637 Wang L, Liang T. 2015. Distribution Characteristics of Phosphorus in the Sediments and 638 Overlying Water of Poyang Lake. PLoS One 10: e01258595.

639 Webster JR, Meyer JL. 1997. Organic matter budgets for streams: A synthesis. JOURNAL OF 640 THE NORTH AMERICAN BENTHOLOGICAL SOCIETY 16: 141-161. 
641 Wilkinson TJ, Huws SA, Edwards JE, Kingston-Smith AH, Siu-Ting K, Hughes M, Rubino F, 642 Friedersdorff M, Creevey CJ. 2018. CowPI: A Rumen Microbiome Focussed Version of the 643 PICRUSt Functional Inference Software. Frontiers in Microbiology 9: e1095.

644 Wollheim WM, Vorosmarty CJ, Bouwman AF, Green P, Harrison J, Linder E, Peterson BJ, 645 Seitzinger SP, Syvitski JPM. 2008. Global N removal by freshwater aquatic systems using a 646 spatially distributed, within-basin approach. Global Biogeochemical Cycles 22: 647 doi:10.1029/2007GB002963.

Yang S, Zhang Y, Cong J, Wang M, Zhao M, Lu H, Xie C, Yang C, Yuan T, Li D, Zhou J, Gu B, Yang Y. 2017. Variations of Soil Microbial Community Structures Beneath Broadleaved Forest Trees in Temperate and Subtropical Climate Zones. Frontiers in Microbiology 8.

Yao L, Chen C, Liu G, Liu W. 2018. Sediment nitrogen cycling rates and microbial abundance 652 along a submerged vegetation gradient in a eutrophic lake. Science of the Total Environment 616: 899-907.

Ylla I, Peter H, Romani AM, Tranvik LJ. 2013. Different diversity-functioning relationship in lake and stream bacterial communities. Fems Microbiology Ecology 85: 95-103.

Zehr JP, Jenkins BD, Short SM, Steward GF. 2003. Nitrogenase gene diversity and microbial community structure: a cross-system comparison. Environmental Microbiology 5: 539-554.

Zhang D, Liao Q, Zhang L, Wang D, Luo L, Chen Y, Zhong J, Liu J. 2015. Occurrence and spatial 659 distributions of microcystins in Poyang Lake, the largest freshwater lake in China. $660 \quad$ Ecotoxicology 24: 19-28.

661 Zhao J, Li J, Yan H, Zheng L, Dai Z. 2011. Analysis on the Water Exchange between the Main 662 Stream of the Yangtze River and the Poyang Lake. Procedia Environmental Sciences 10: 22566632264. 
664 Zumft WG. 1997. Cell biology and molecular basis of denitrification. Microbiology and Molecular 665 Biology Reviews 61: 533-616.

666 
Figure 1 (on next page)

Study area and sampling sites

Study area and sampling sites. Samples were collected from the surface water and sediment of Poyang lake and its fiver tributaries (Xiushui, Ganjiang, Fuhe, Xinjiang, and Raohe). This figure was modified from Ren et al, 2019 


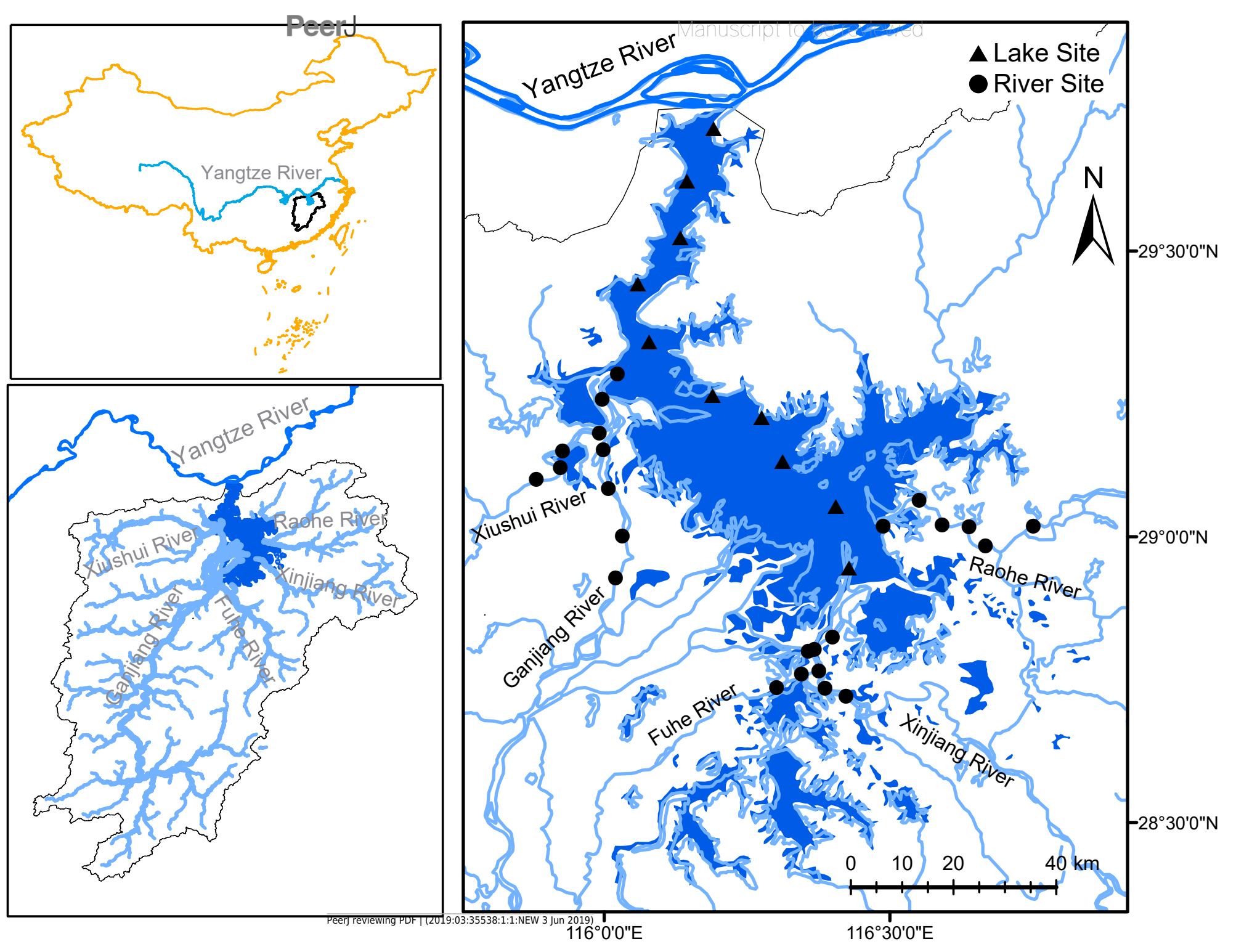


Figure 2 (on next page)

Functional differences between habitats

Functional differences between habitats. (A-E) Non-metric multidimensional scaling analysis of potential functions composition in terms of overall functions, carbon metabolism, nitrogen metabolism, phosphorus cycle, and sulfur metabolism. (F) Pairwise dissimilarity tests of functional composition between different habitats using ADONIS. The numbers outside the bracket are " $\mathrm{R}^{2 "}$. P-values are in bracket. 


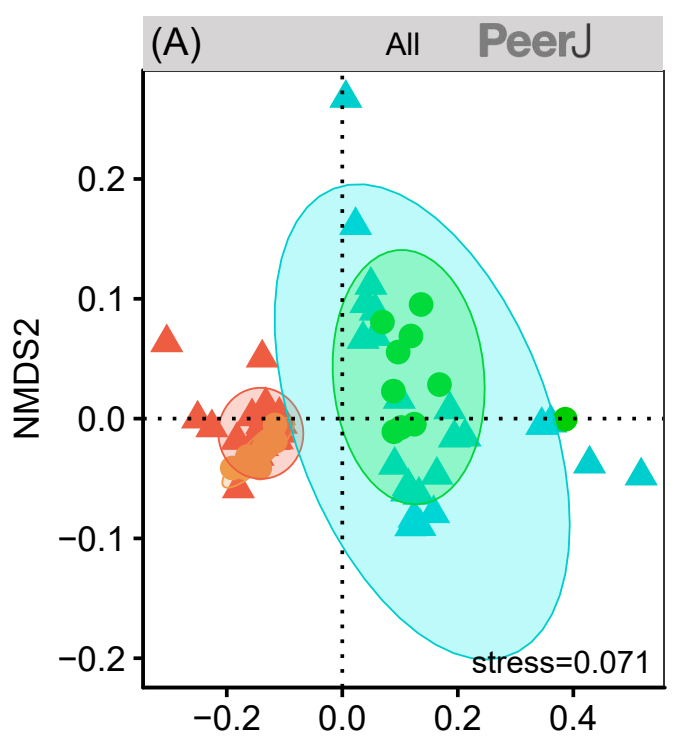

(B) Carbon Metabolismanuscript to be review (C) Nitrogen Metabolism
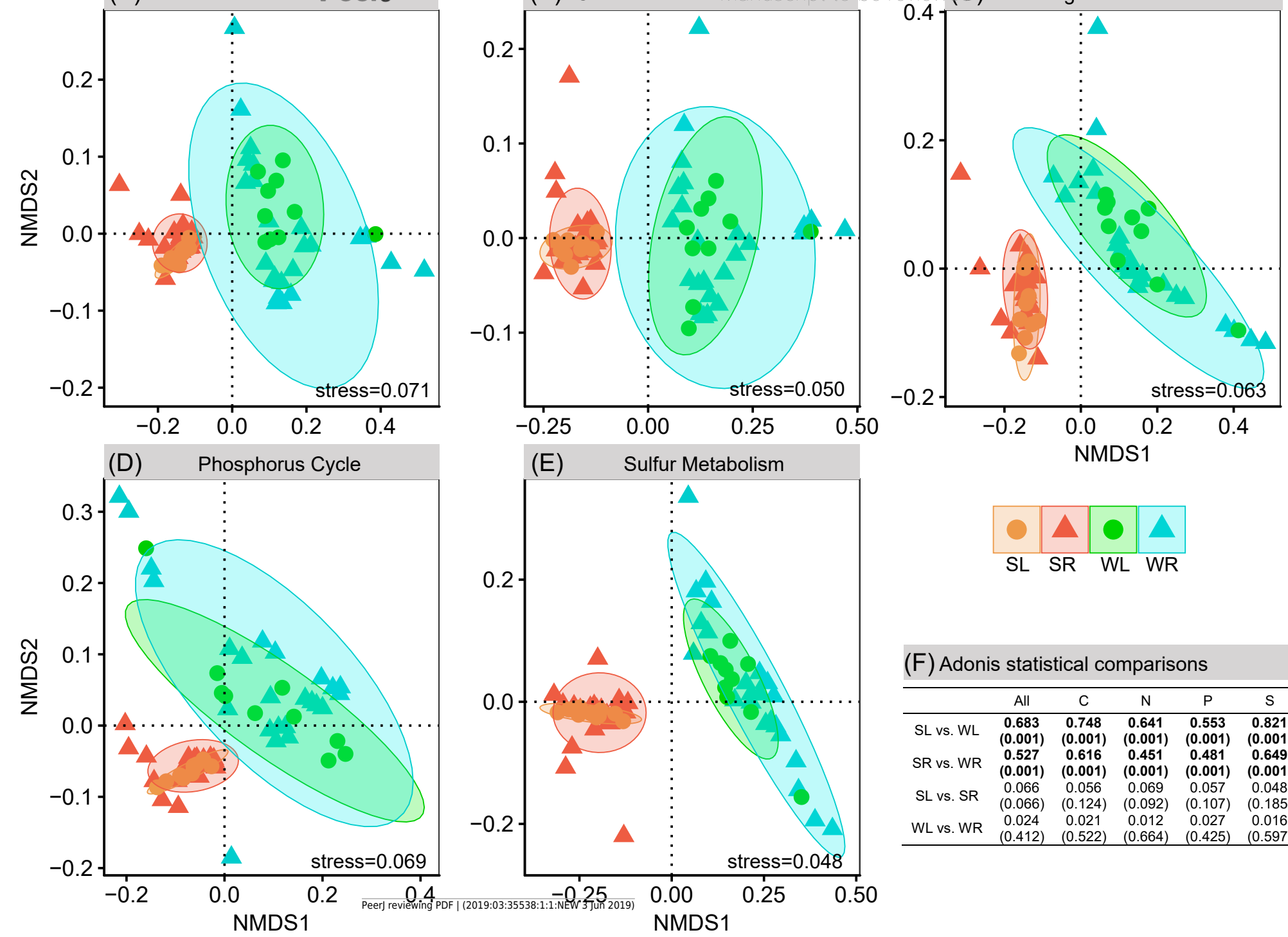

(F) Adonis statistical comparisons

\begin{tabular}{cccccc}
\hline & All & C & N & P & S \\
\hline SL vs. WL & $\mathbf{0 . 6 8 3}$ & $\mathbf{0 . 7 4 8}$ & $\mathbf{0 . 6 4 1}$ & $\mathbf{0 . 5 5 3}$ & $\mathbf{0 . 8 2 1}$ \\
& $\mathbf{( 0 . 0 0 1 )}$ & $\mathbf{( 0 . 0 0 1 )}$ & $\mathbf{( 0 . 0 0 1 )}$ & $(\mathbf{0 . 0 0 1 )}$ & $\mathbf{( 0 . 0 0 1 )}$ \\
SR vs. WR & $\mathbf{0 . 5 2 7}$ & $\mathbf{0 . 6 1 6}$ & $\mathbf{0 . 4 5 1}$ & $\mathbf{0 . 4 8 1}$ & $\mathbf{0 . 6 4 9}$ \\
& $(\mathbf{0 . 0 0 1 )}$ & $\mathbf{( 0 . 0 0 1 )}$ & $\mathbf{( 0 . 0 0 1 )}$ & $(\mathbf{0 . 0 0 1 )}$ & $\mathbf{( 0 . 0 0 1 )}$ \\
SL vs. SR & 0.066 & 0.056 & 0.069 & 0.057 & 0.048 \\
& $(0.066)$ & $(0.124)$ & $(0.092)$ & $(0.107)$ & $(0.185)$ \\
WL vs. WR & 0.024 & 0.021 & 0.012 & 0.027 & 0.016 \\
& $(0.412)$ & $(0.522)$ & $(0.664)$ & $(0.425)$ & $(0.597)$ \\
\hline \multicolumn{6}{c}{} \\
& & & & & \\
& & & & & \\
& & & & &
\end{tabular}


Figure 3 (on next page)

Relative abundance of genes associated to major pathways

Relative abundance of genes associated to major pathways in (A) central carbon metabolism, (B) nitrogen metabolism, (C) phosphorus cycle, and (D) sulfur metabolism. For each pathway, the same lowercase letter indicates a non-significant difference, whereas the different letter indicates a significant difference between habitats (ANOVA, $P<0.05$ ). P-values were adjusted by FDR correction 


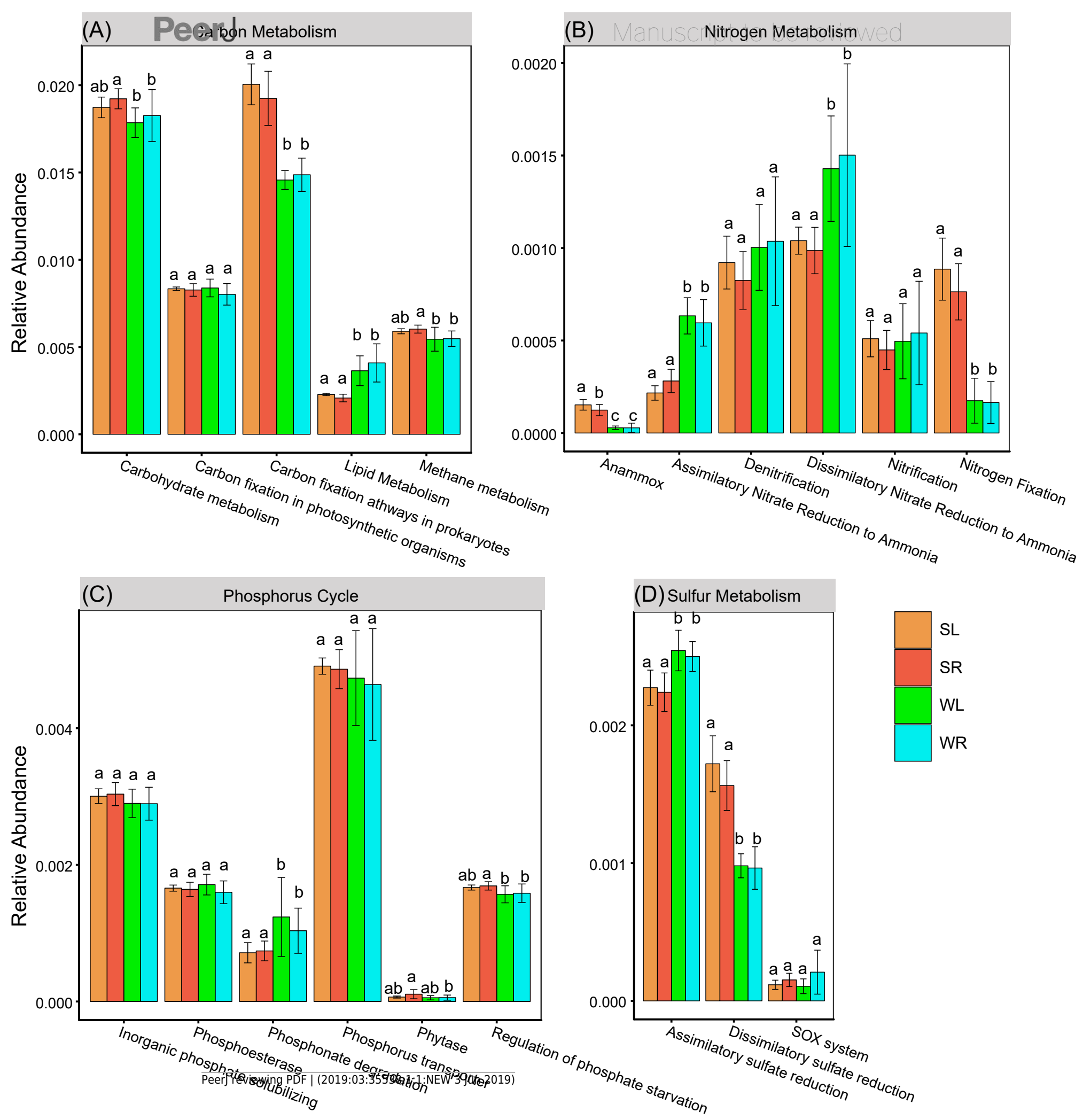


Figure 4 (on next page)

Biplot of distance-based redundancy analyses (dbRDA)

Biplot of distance-based redundancy analyses (dbRDA) showing the relationship between functional composition and nutrient variables in (A) sediment and (B) water. The red arrows represent the significant variables (envfit, $P<0.05$ ) 
Figure $\mathbf{5}$ (on next page)

Mantel tests between major functions and nutrient variables

Mantel tests between major functions and nutrient variables of $(A)$ sediment and (B) water based on Spearman correlation. Significant correlations $(P<0.05)$ were colored. P-values were adjusted by FDR correction 


\section{(A) Sediment}

\section{(B) Water}

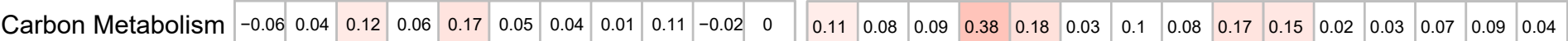
Nitrogen Metabolism

Phosphorus Cycle

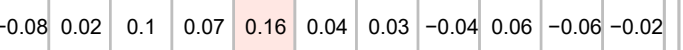

\begin{tabular}{l|l|l}
0.06 & 0.03 & 0.07
\end{tabular}

$\begin{array}{lllllll}0.44 & 0.16 & -0.02 & 0.13 & 0.03 & 0.16\end{array}$

\begin{tabular}{|l|l|l|l|l|l|l|}
0.16 & 0.11 & 0.04 & 0 & 0.09 & 0.09 & 0 \\
\hline
\end{tabular}

Sulfur Metabolism

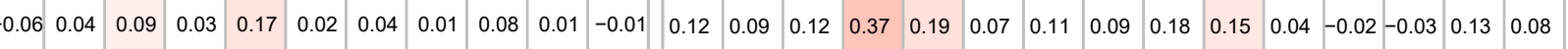

\begin{tabular}{|l|l|l|l|l|l|l|l|l|l|l|}
\hline-0.04 & 0.03 & 0.13 & 0.08 & 0.16 & 0.04 & 0.06 & 0.01 & 0.05 & -0.03 & -0.03 \\
\hline
\end{tabular}

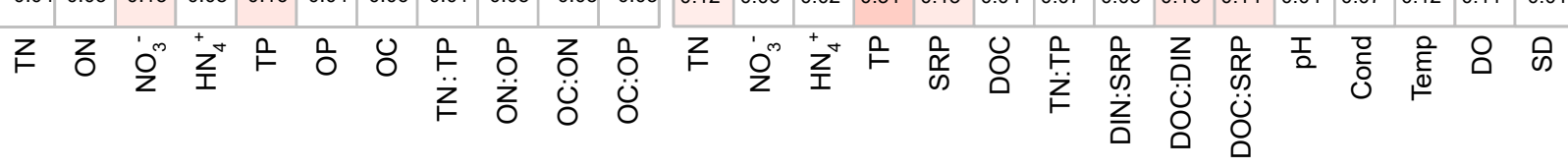

$\left[\begin{array}{c}1 \\ 0.8 \\ 0.6 \\ 0.4 \\ 0.2 \\ 0 \\ -0.2 \\ -0.4 \\ -0.6 \\ -0.8 \\ -1\end{array}\right.$

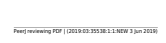


Figure 6 (on next page)

Linear regressions between taxonomic and functional dissimilarities

(A-E) Linear regressions between taxonomic and functional dissimilarities. One point represents one sample pair. Shadow area denotes the $95 \%$ confidence interval. (F-G) Statistical test of the linear regression slopes between systems and within systems using ANCOVA 


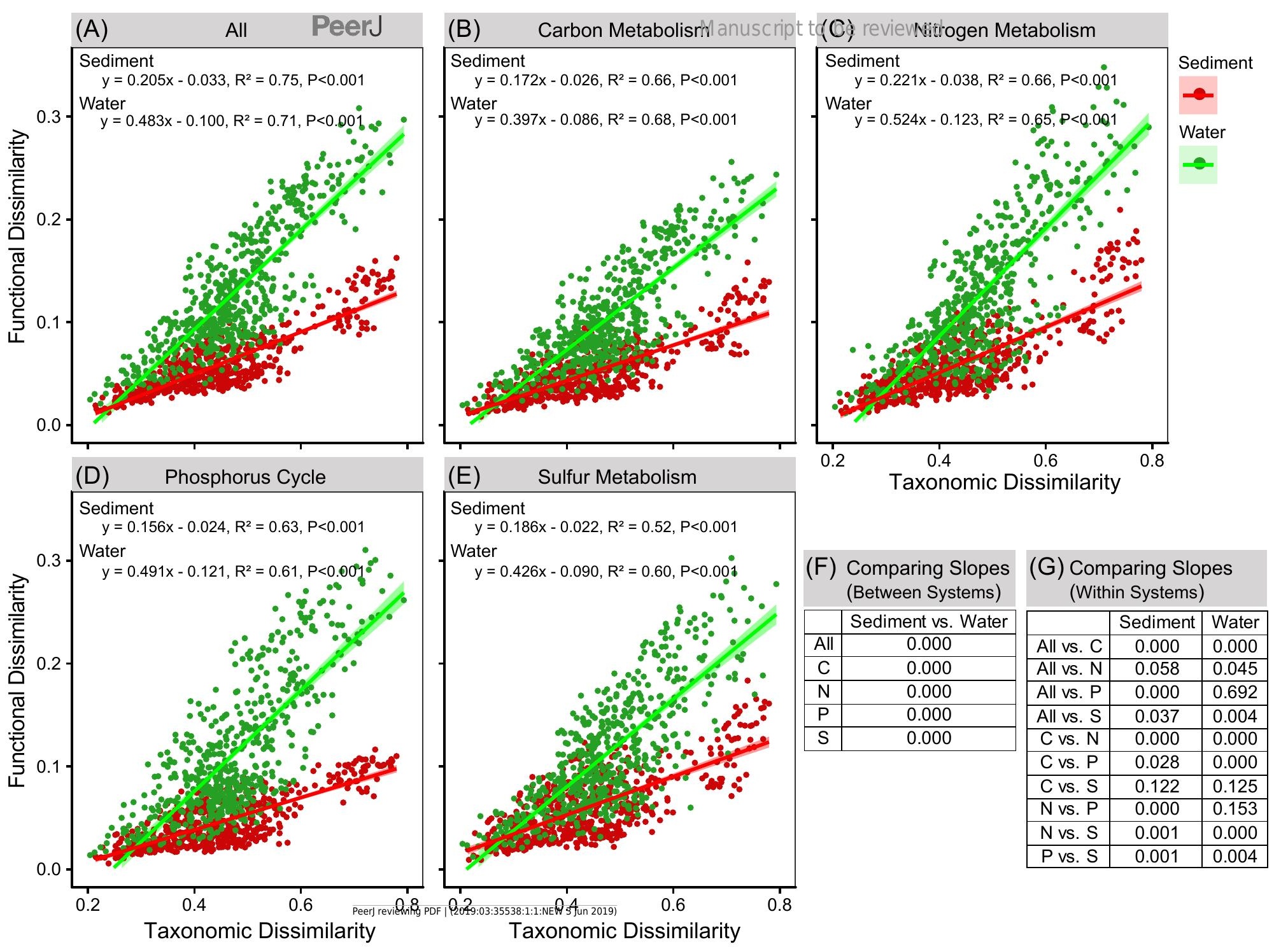

